\title{
PEMBERDAYAAN PETANI DESA CANDIJATI DALAM PENCEGAHAN COVID-19 DAN PENINGKATAN STATUS EKONOMI MELALUI PEMBUATAN MASKER JERAMI AROMATERAPI
}

\author{
Ika Rahmawati Sutejo ${ }^{1 *}$, Adistha Eka Noveyani ${ }^{2}$, Avita Lukmawati ${ }^{3}$ \\ ${ }^{1}$ Fakultas Kedokteran, ${ }^{2}$ Fakultas Kesehatan Masyarakat, ${ }^{3}$ Fakultas Pertanian \\ Universitas Jember. Jl. Kalimantan 37 Jember Jawa Timur \\ Email Korespondensi: ikarahmawati.fk@unej.ac.id
}

Disubmit: 2 November $2021 \quad$ Diterima: 23 Desember $2021 \quad$ Diterbitkan: 02 Januari 2022 DOI: https://doi.org/10.33024/jkpm.v1i1.5404

\begin{abstract}
ABSTRAK
Mayoritas masyarakat Desa Candijati Arjasa Jember Jawa Timur bekerja di bidang pertanian (64\%). Desa Candijati merupakan penghasil padi terbanyak di Kecamatan Arjasa. Petani desa Candijati termasuk golongan masyarakat terdampak pandemi corona. Pembatasan mobilitas membuat petani kesulitan memasarkan produk pertaniannya. Harga produk pertanian menjadi anjlok. Pendapatan petani menjadi turun drastis. Hal ini mencetuskan kecemasan dan stress pada petani. Petani juga menghadapi ancaman terpapar covid selama pandemi, karena tidak mendapat informasi mengenai penyakit dan pencegahan yang benar. Berdasarkan permasalahan tersebut, tim pengusul pengabdian menawarkan solusi kepada mitra petani kelompok tani Desa Candijati berupa penyuluhan mengenai penyakit covid dan pencegahannya serta pelatihan membuat masker beraromaterapi. Tujuan pengabdian ini adalah mencegah paparan Covid dan mengurangi stress pada petani serta meningkatkan status ekonomi petani. Metode kegiatan terdiri dari identifikasi keluhan/penyakit petani, pemberian penyuluhan mengenai penyakit dan pencegahannya, dan pelatihan pembuatan tisue aromaterapi. Tisue aromaterapi yang terbuat dari jerami dan ditambahkan aroma jeruk disisipkan ke dalam masker kain 2 lapis. Selain mencegah paparan virus covid, aroma jeruk pada tisue saat dipakai dalam masker dapat meredakan kecemasan sehingga membantu mengurangi stress yang dialami petani. Sasaran kegiatan ini adalah ibu-ibu petani desa Candijati kecamatan Arjasa. Hasil akhir kegiatan ini berupa produk masker aromaterapi, peningkatan ketrampilan, pemahaman dan kesehatan masyarakat.
\end{abstract}

Kata Kunci: masker, aromaterapi, tisue, jerami, petani

\begin{abstract}
The majority of the people of Candijati Arjasa Jember East Java work in agriculture (64\%). Candijati village is the largest rice producer in Arjasa district. Candijati farmers are part of the community affected by the corona pandemic. Restrictions on mobility make it difficult for farmers to market their agricultural products. Prices of agricultural products have fallen. Farmers' incomes have fallen drastically. This triggers anxiety and stress in farmers. Farmers also face the threat of being exposed to covid during the pandemic, because they do not get information about the disease and proper prevention.
\end{abstract}


Based on these problems, the team offered solutions to farmer of Candijati Village in the form of counseling about the covid disease and its prevention as well as training to make aromatherapy masks. The purpose of this program is to prevent exposure to Covid, reduce stress and improve the economic status of farmers. The method of activity consists of identifying farmer complaints/diseases, providing counseling about diseases and their prevention, training in making aromatherapy tisue. This aromatherapy tissue made from straw and added with the aroma of citrus is inserted into a 2-ply cloth mask. In addition to preventing exposure to the covid virus, the smell of citrus on tissues when used in masks can relieve anxiety so that it helps reduce stress. The target of this activity is the farmers of Candijati village, Arjasa sub-district. The end result of this activity is aromatherapy mask products, skill improvement, understanding and public health.

Keywords: masks, aromatherapy, tissue, straw, farmers

\section{PENDAHULUAN}

Data statistik menunjukkan jumlah petani di kabupaten Jember, Jawa Timur sebanyak $60 \%$ total penduduk (BPS, 2021). Luas wilayah kabupaten Jember mencapai $3.293 \mathrm{~km}^{2}$, luas tanah sawah $85.794 \mathrm{Ha}$ dan 365 ribu orang bekerja sebagai petani. Sekitar 37\% dari jumlah tersebut berusia lebih dari 55 tahun. Kecamatan Arjasa merupakan salah satu kecamatan di bagian utara Jember, terdiri dari 6 Desa. Mayoritas masyarakat desa Candijati bekerja di bidang pertanian (64\%) dan merupakan area penghasil padi terbanyak di Kecamatan Arjasa dan dari $920 \mathrm{KK}$ di desa Candijati yang bekerja sebagai petani, terdapat 682 KK tidak memiliki lahan pertanian sendiri, sehingga sebagian besar merupakan petani gurem (BPS, 2021). Kelompok ini rentan mengalami permasalahan baik ekonomi maupun kesehatan.

Petani termasuk kelompok masyarakat yang terkena dampak pandemi COVID-19. Banyak petani mengalami stress dan kecemasan karenanya. Permasalahan yang dihadapi petani sekarang cukup banyak, kelangkaan pupuk, cuaca yang ekstrim sehingga terdapat ancaman gagal panen, sampai dengan harga komoditas pertanian yang murah akibat daya beli masyarakat dan permintaan pasar turun selama pandemi. Pembatasan sosial berskala besar (PSBB) menyulitkan petani memasarkan produk hasil pertanian (Sarni, 2020). Pandemi covid semakin membuat petani kesulitan ekonomi. Bila ada keluarga petani yang terserang covid, mereka dan lingkungan sekitar harus menjalankan isolasi yang membatasi aktivitas mencari nafkah. Sebagian besar petani yang berusia lanjut, apabila terpapar virus Covid, juga menghadapi ancaman kondisi berat hingga kematian karena komorbid yang dimiliki.

Tim pengabdian memanfaatkan limbah yang ada di sekitar petani untuk mengatasi permasalahan petani. Petani seringkali kali mengganggap jerami padi tidak memiliki nilai ekonomis. Jerami mengandung 35,61\% selulosa, 26,96\% hemiselulosa dan 10,79\% lignin (Syazwanee, 2018), sehingga dapat dimanfaatkan sebagai bahan baku tisue. Produk tisu yang dihasilkan dari jerami bersifat biodegradable (Nguyen, 2019). Tisu kering berbahan jerami akan ditambah dengan minyak aroma terapi cirus/jeruk yang dapat meredakan kecemasan sehingga membantu menenangkan pikiran petani. Kandungan minyak pada citrus aurantium memiliki efek penenang. Kandungan tersebut ialah limonene $(96,24 \%)$, linalool $(0,44 \%)$, linaly asetat, geranyl asetat, geraniol, nerol, neryl 
acetate. Cahyati et al. (2016) menyebutkan kandungan linalool bersifat sebagai penenang.

Tisue beraromaterapi ini disisipkan pada masker kain 2 lapis. Masker ini akan digunakan oleh petani selama beraktivitas untuk melindungi saluran napas \& mulut dari paparan virus covid. Masker beraromaterapi ini diharapkan memberi kenyamanan pada pengguna, sehingga pemakai betah tidak melepas maskernya karena terdapat sensasi menyegarkan. Kelebihan lain masker ini dapat membantu mengurangi kecemasan \& stress yang dialami pemakainya. Selain itu juga dapat berfungsi sebagai alat uji indra penciuman, memastikan ada tidaknya anosmia pemakainya. Menurut Hosseini et al. (2020) salah satu gejala terinfeksi COVID 19 yaitu tidak dapat mencium bau atau anosmia. Tisue ini membantu deteksi dini infeksi covid pada petani. Sehingga tim pengusul menilai program yang dilaksanakan dapat membantu masyarakat terdampak covid melalui kegiatan dengan judul Pemberdayaan Petani Desa Candijati dalam Pencegahan Covid dan Peningkatan Status Ekonomi melalui Pembuatan Masker Jerami Aromaterapi.

\section{MASALAH}

Tim pengusul mengkaji permasalahan yang ada dan berusaha merancang solusi dengan memanfaatkan sumberdaya di sekitar petani. Petani dihadapkan dilema harus tetap beraktivitas mencari nafkah dengan ancaman terkena covid. Petani di daerah pedesaan juga menjadi golongan masyarakat yang minim pengetahuan mengenai penyakit ini. Mereka jarang mendapat edukasi, seringkali mendengar berita hoax tentang covid, tidak paham tentang gejala penyakit dan pencegahannya. Petani juga mengalami kecemasan \& peningkatan stress selama pandemi. Limbah jerami padi yang banyak dihasilkan setelah panen, kurang dimanfaatkan. Jerami biasanya hanya digunakan sebagai pakan hewan ternak atau dibakar.

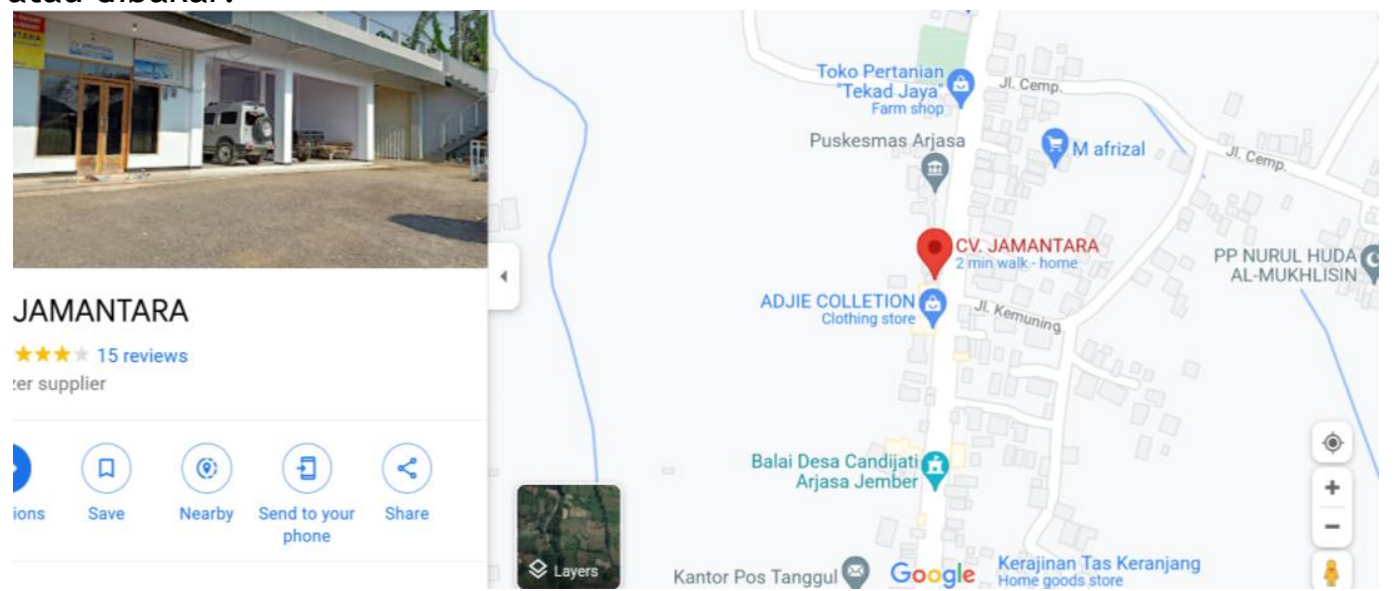

Gambar 1. Peta wilayah \& Lokasi Kegiatan

\section{METODE}

Rangkaian kegiatan dilaksanakan pada bulan September-Nopember tahun 2021 dengan sasaran ibu-ibu petani yang tergabung pada kelompok tani desa Candijati kecamatan Arjasa. Kegiatan ini menekankan peran mitra dalam membuat tisue dan masker aromaterapi serta memahami cara pemakaian masker yang benar untuk mencegah terpapar covid. Kegiatan dilaksanakan melalui beberapa tahap, meliputi: 
1) Identifikasi keluhan kesehatan yang sering dialami petani

2) Penyuluhan mengenai penyakit covid dan pencegahannya, salah satunya dengan menekankan pentingnya penggunaan masker yang tepat dan benar

3) Pelatihan membuat tisue dari jerami yang ditambahkan aromaterapi jeruk. Tisue beraromaterapi ini disisipkan ke dalam masker 2 lapis. Selain mencegah paparan virus covid, masker aromaterapi ini juga meredakan kecemasan

4) Menggagas pembentukan wirausaha pembuatan masker aromaterapi yang digawangi oleh mitra.

Identifikasi keluhan kesehatan yang sering dialami petani dilakukan melalui pemberian kuesioner. Tim memberikan penyuluhan tentang penyakit dan pemakaian masker yang benar untuk pencegahan terpapar covid. Pelatihan pembuatan tisue dan masker jerami aromaterapi diberikan kepada ibu-ibu petani desa Candijati. Sebelum dilatihkan pada sasaran, uji coba pembuatan tisue jerami telah dilaksanakan di laboratorium Fakultas Pertanian Universitas Jember selama 1 bulan. Formula pembuatan tisue dapat diduplikasi dengan mudah oleh ibu-ibu petani dan tisue yang dihasilkan berkualitas baik (Gambar 2). Pelatihan dilaksanakan selama 4 jam dengan memperhatikan protokol kesehatan masa pandemi. Kegiatan ini dilaksanakan di rumah ketua kelompok tani Desa Candijati Kecamatan Arjasa Jember (Gambar 1)

Jerami dipotong kecil, dikeringkan (dioven 175 menit suhu $90^{\circ} \mathrm{C}$ ), dihaluskan menjadi serbuk

Membuat pulp coklat: 25 gram serbuk jerami dicampur $750 \mathrm{~mL} \mathrm{NaOH} \mathrm{(} 80 \mathrm{~g} \mathrm{NaOH}$ dilarutkan menjadi $1 \mathrm{~L}$ ) dipanaskan 1,5 jam. Pulp coklat dicuci dengan aquades

Membuat pulp putih: Pulp coklat dibleaching dengan $\mathrm{H}_{2} \mathrm{O}_{2} 2 \% 500 \mathrm{~mL}$, dipanaskan di atas hotplate selama 1 jam suhu $60^{\circ} \mathrm{C}$, kemudian disaring dan dicuci

Pulp putih ditambah VCO $4 \mathrm{~mL}$; tapioka 0,3 gram; chitosan 0,3 gram; dan aquades $500 \mathrm{~mL}$, didiamkan satu malam, kemudian campur dengan mixer

Adonan pulp ditambah air sebanyak 7 liter kemudian dicetak dan dikeringkan menjadi tisue. Setelah kering disemprot dengan ekstrak aromaterapi.

Adonan pulp ditambah air 7 liter. cetak dan dikeringkan menjadi tisue. Setelah kering disemprot ekstrak aromaterapi.

Produk tisu aromaterapi siap dikemas/digunakan

Gambar 2. Tahapan Pembuatan Tisue Aromaterapi 


\section{HASIL DAN PEMBAHASAN}

\section{a. HASIL}

Hasil evaluasi kuesioner menunjukkan keluhan kesehatan yang sering dialami petani adalah nyeri sendi, linu, sakit pinggang dan stress/kecemasan (gambar 3a). Sedangkan hasil evaluasi pengetahuan dan sikap sasaran ibu-ibu petani melalui pengisian kuesioner sebelum dan sesudah penyuluhan menunjukkan mayoritas terjadi peningkatan pengetahuan (gambar 3b).

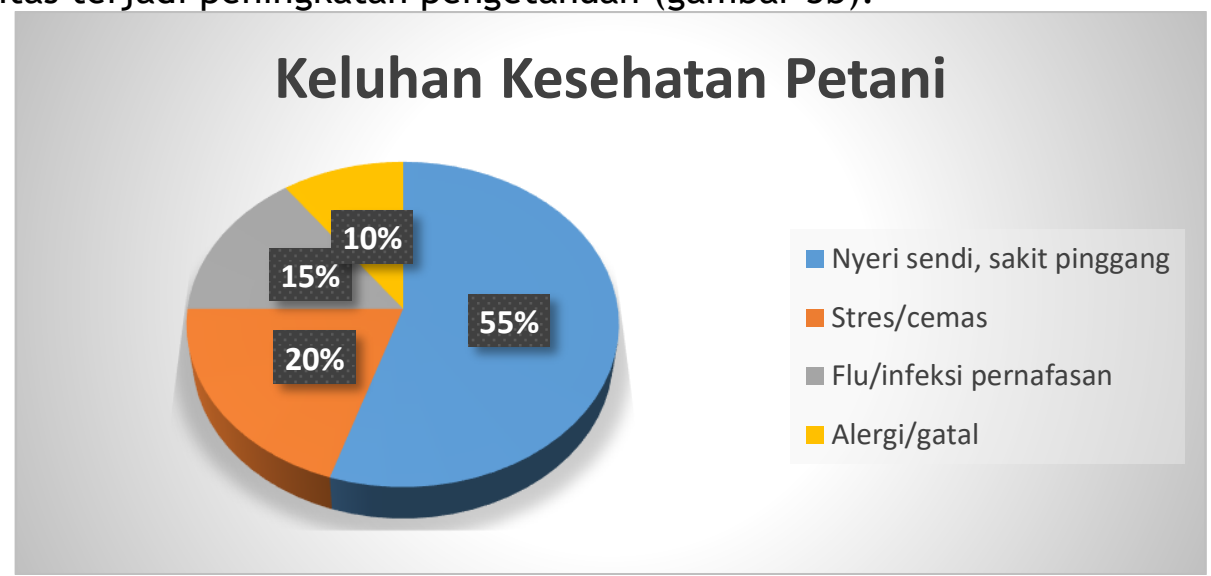

Gambar 3a. Hasil Kuesioner Keluhan Kesehatan Petani

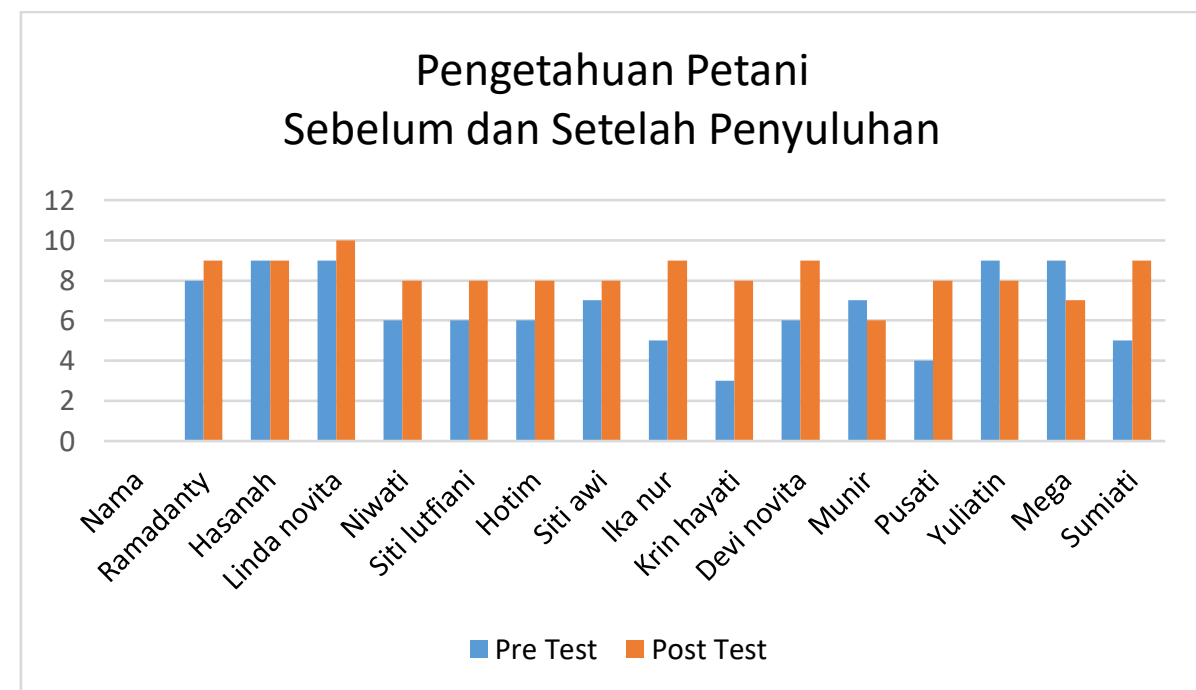

Gambar 3b. Pengetahuan Petani sebelum dan Sesudah Penyuluhan

Gambar 4a menunjukkan kegiatan penyuluhan yang diberikan kepada ibu-ibu petani desa Candijati. Kegiatan ini diikuti oleh 25 peserta dengan memerhatikan protokol kesehatan masa pandemi. Materi yang diberikan meliputi pengetahuan mengenai penyakit covid dan cara pencegahannya,terutama bagaimana memilih dan menggunakan masker yang benar. Peserta penyuluhan juga diminta mempraktekkan cara menggunakan masker yang tepat sehingga dapat mencegah paparan covid. Peserta pelatihan mempraktekkan cara menggunakan masker yang tepat ditunjukkan pada Gambar 4b. Pada saat penyuluhan juga dibagikan masker dan suplemen multivitamin untuk peserta. 


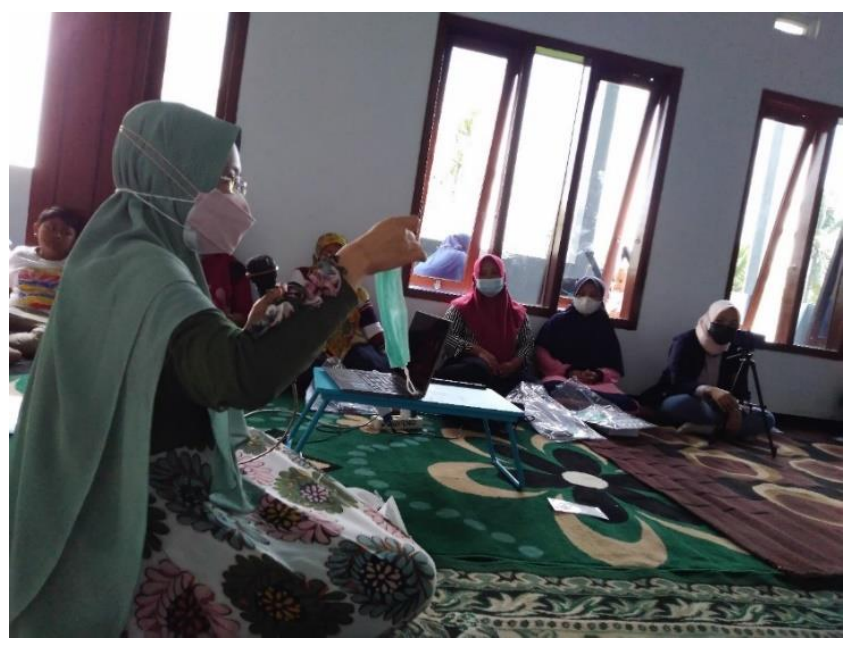

Gambar 4. (a) Kegiatan penyuluhan

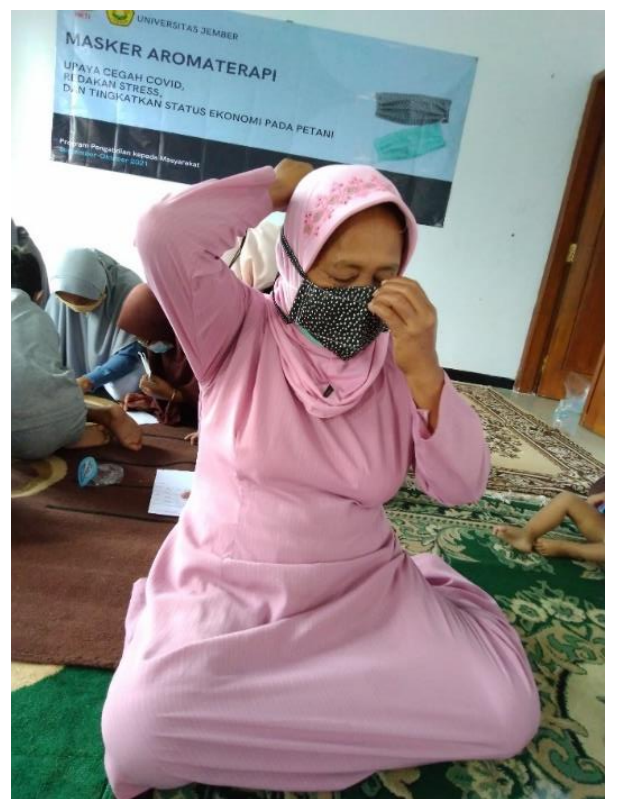

Gambar 4. (b) Peserta mempraktekkan cara menggunakan masker yang tepat

Kegiatan pelatihan pembuatan tisue jerami aromaterapi dilakukan kepada 20 orang sasaran yang berasal dari ibu-ibu petani. Peserta diajak mempraktekkan mulai dari membuat serbuk jerami sampai dengan mencetak dan mengeringkan tisue jerami. Pada pertemuan pertama peserta diwajibkan mencoba sehingga tim dapat mengevaluasi dan memberi masukan langkah pembuatan tisue apakah sudah tepat atau belum. Kegiatan pelatihan dan produk yang dihasilkan dapat dilihat pada Gambar 5. Kegiatan pendampingan \& evaluasi produksi tisue dan masker aromaterapi yang dikerjakan oleh mitra dilaksanakan dengan tim mendatangi rumah mitra untuk mematau keberlangsungan produksi masker oleh ibu-ibu petani. 


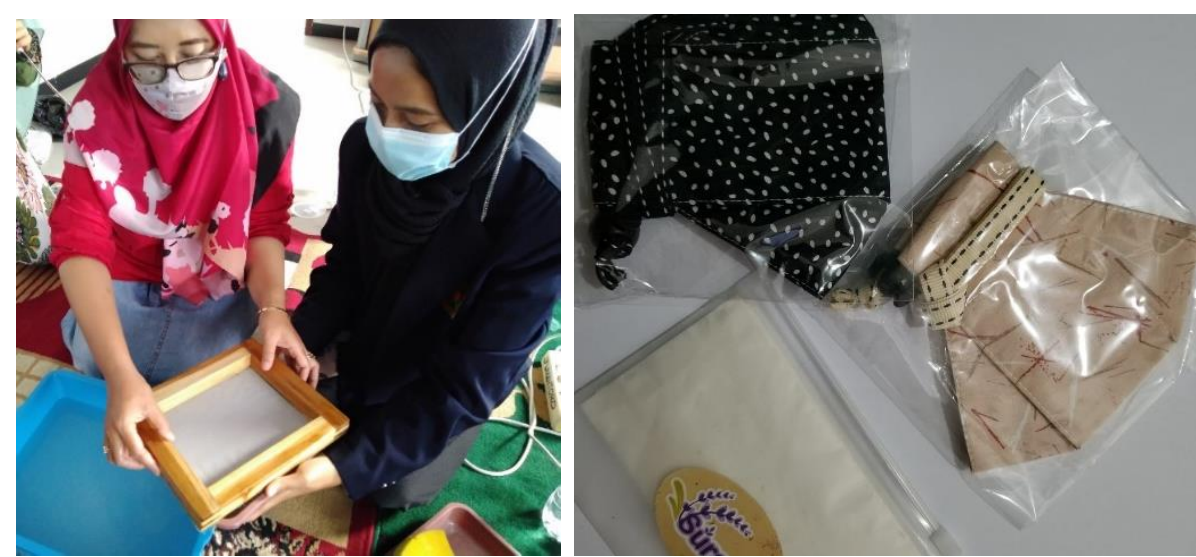

Gambar 5. Peserta mencoba sendiri membuat tisue aromaterapi didampingi oleh tim pengabdian masyarakat \& produk masker yang dihasilkan

\section{b. PEMBAHASAN}

Sasaran yang dipilih pada kegiatan ini adalah ibu-ibu petani dengan pertimbangan ibu merupakan pengawas utama kesehatan seluruh anggota keluarga. Ibu-ibu petani ini juga lebih terampil dan dapat mengatur waktu luang dibandingkan bapak-bapak petani yang lebih banyak menghabiskan waktu di sawah. Ibu petani mempunyai akses langsung pada jerami sehingga dapat mendapatkan bahan baku dengan mudah dan tanpa membeli.

Tiga keluhan kesehatan paling banyak dijumpai pada petani adalah gangguan otot dan tulang (musculoskletal), selain kecemasan dan infeksi saluran napas. Hal ini diakibatkan kesalahan posisi dan beban kerja berulang. Postur kerja yang salah saat mengangkat beban berat dan postur membungkuk atau jongkok yang dilakukan saat melakukan kegiatan bertani merupakan faktor risiko penyebab keluhan ini (Kaur, 2016).

Terdapat peningkatan pengetahuan pada hasil post test setelah penyuluhan ini menunjukkan efektifnya penyuluhan yang diberikan. Hal ini sesuai penelitian Abdullah (2021) yang menyatakan kampanye pemutusan mata rantai Covid-19 melalui penyuluhan dapat meningkatkan pengetahuan masyarakat dan mempengaruhi sikapnya dalam pemutusan penyebaran virus corona. Materi yang disampaikan dalam penyuluhan merupakan materi yang benar-benar dibutuhkan oleh ibu-ibu petani, materi juga disampaikan dengan bahasa yang sederhana dan jelas sehingga mudah dipahami. Selain itu dalam proses penyuluhan juga ada sesi mempraktikkan apa yang sudah dipelajari misalnya cara memakai masker dan cara membuang masker. Hal ini juga yang membuat peserta penyuluhan benarbenar memahami materi yang disampaikan.

Penggunaan masker yang benar untuk mencegah terpapar covid adalah masker medis yang dipakai dengan ketat, menutup hidung mulut dan dagu. Masker medis jenis KF94 atau KN95 memenuhi persyaratan ini sehingga dapat digunakan tunggal. Masker bedah sekali pakai didisain longgar, sehingga disarankan dipakai dobel dengan masker kain di bagian luarnya. Masker kain dua lapis juga dapat digunakan. Bahan kain dengan kemampuan filtrasi paling baik adalah dari jenis katun, tidak dianjurkan memilih masker kain berbahan kaos atau scuba karena pori-pori kain yang lebar dapat ditembus virus. Masker digunakan maksimal 4 jam, atau harus segera diganti saat kotor atau basah.

Alat yang digunakan dalam proses produksi tisue jerami meliputi oven, alat pemotong, blender, beaker glass, hot plate/kompor, saringan, dan cetakan (kasa 200 mesh). Sedangkan bahan yang digunakan meliputi jerami padi, $\mathrm{NaOH}$, aquades, H2O2, VCO, tapioka, dan kitosan. Tahapan proses pembuatan terbagi 
menjadi 4, yaitu 1) mendapatkan serbuk jerami, 2) pulping yang menghasilkan adonan pulp berwarna coklat, 3) bleaching, yang menghasilkan adonan pulp berwarna putih, dan 4) mencetak tisue jerami dengan cetakan mess serta mengeringkannya. Tisue yang dihasilkan ditambahkan aromaterapi kemudian disisipkan ke dalam masker kain 2 lapis. Masker ini selain mencegah paparan virus covid juga membantu meredakan stres. Masker yang diproduksi ibu-ibu petani terdiri dari 3 lapis. Jenis bahan kain yang dipakai adalah katun, dengan desain menutupi seluruh hidung mulut dan dagu. Masker berbentuk 3D yang mempunyai ruang untuk mempermudah pemakainya bernapas, sehingga lebih nyaman. Masker juga dilengkapi dengan stoper agar saat diperlukan untuk dilepas sementara, masker dapat tetap terkalung di leher. Hal ini menghindari masker kotor dan terkontaminasi jika diletakkan di sembarang tempat, misalnya jika pengguna makan.

\section{KESIMPULAN}

Kegiatan pengabdian dengan tujuan memberdayakan petani untuk mencegah terpapar Covid, mengatasi kecemasan, dan meningkatkan status ekonomi telah dilakukan melalui penyuluhan kesehatan dan pelatihan pembuatan masker. Kegiatan berjalan lancar ditandai dengan peningkatan pengetahuan mitra, antusiasme peserta dan adanya produk masker aromaterapi yang telah dipasarkan.

\section{UCAPAN TERIMA KASIH}

Terima kasih kepada Universitas Jember yang telah mendanai kegiatan ini melalui Hibah Pengabdian Kemitraan pendanaan DIPA Universitas Jember tahun anggaran 2021 dengan SPK No. 023.17.2.677562.2021.

\section{DAFTAR PUSTAKA}

Abdullah, V. I. (2021). Kampanye Pemutusan Mata Rantai Penularan Covid-19 Melalui Edukasi Kesehatan Pada Masyarakat DTPK. Jurnal Kreativitas Pengabdian Kepada Masyarakat (PKM), 4(1), 219-225.

BPS. 2021. Jember dalam Angka 2021. Jember: CV. Azka Putra Pratama.

Cahyati, S., Kurniasih, Y., \& Khery, Y. (2016). Efisiensi Isolasi Minyak Atsiri Dari Kulit Jeruk Dengan Metode Destilasi Air-Uap Ditinjau Dari Perbandingan Bahan Baku Dan Pelarut Yang Digunakan. Hydrogen: Jurnal Kependidikan Kimia, 4(2), 103-110.

Hosseini, A., Mirmahdi, E., \& Moghaddam, M. A. (2020). A new strategy for treatment of Anosmia and Ageusia in COVID-19 patients. Integrative Respiratory Medicine, 1, 2.

Kaur, K. (2016). Prevalensi Keluhan Low Back Pain (LBP) pada Petani di Wilayah Kerja UPT Kesmas Payangan Gianyar April 2015. Intisari Sains Medis, 5(1), 49-59.

Nguyen, A. T., \& Nguyen, M. N. (2019). Straw phytolith for less hazardous open burning of paddy straw. Scientific reports, 9(1), 1-6.

Sarni, S., \& Sidaya, M. (2020, November). DAMPAK PANDEMI COVID 19 TERHADAP PENDAPATAN PETANI SAYURAN DI KOTA TERNATE. In Prosiding Seminar Nasional Agribisnis (Vol. 1, No. 1).

Syazwanee, M. M. F., Shaziera, A. N., Izzati, M. N. A., Azwady, A. N., \& Muskhazli, M. (2018). Improvement of delignification, desilication and cellulosic content availability in paddy straw via physico-chemical pretreatments. Annual Research \& Review in Biology, 1-11. 